\title{
"The effect of the crisis on financial performance of property sector in Indonesia"
}

\begin{tabular}{|c|c|c|}
\hline AUTHORS & \multicolumn{2}{|c|}{ Elok Sri Utami (D https://orcid.org/0000-0003-4652-0151 } \\
\hline ARTICLE INFO & \multicolumn{2}{|c|}{$\begin{array}{l}\text { Elok Sri Utami (2017). The effect of the crisis on financial performance of property } \\
\text { sector in Indonesia. Investment Management and Financial Innovations, 14(1-1), } \\
\text { 248-253. doi:10.21511/imfi.14(1-1).2017.11 }\end{array}$} \\
\hline DOI & \multicolumn{2}{|c|}{ http://dx.doi.org/10.21511/imfi.14(1-1).2017.11 } \\
\hline RELEASED ON & \multicolumn{2}{|l|}{ Friday, 12 May 2017} \\
\hline RECEIVED ON & \multicolumn{2}{|l|}{ Saturday, 28 January 2017} \\
\hline ACCEPTED ON & \multicolumn{2}{|l|}{ Monday, 10 April 2017} \\
\hline LICENSE & \multicolumn{2}{|c|}{$\begin{array}{l}\text { This work is licensed under a Creative Commons Attribution } 4.0 \text { International } \\
\text { License }\end{array}$} \\
\hline JOURNAL & \multicolumn{2}{|c|}{ "Investment Management and Financial Innovations" } \\
\hline ISSN PRINT & \multicolumn{2}{|l|}{$1810-4967$} \\
\hline ISSN ONLINE & \multicolumn{2}{|l|}{$1812-9358$} \\
\hline PUBLISHER & \multicolumn{2}{|c|}{ LLC "Consulting Publishing Company "Business Perspectives" } \\
\hline FOUNDER & \multicolumn{2}{|c|}{ LLC "Consulting Publishing Company "Business Perspectives" } \\
\hline$\delta^{0}$ & 4 & $\begin{array}{l}\text { 三E: } \\
\text { 三E三 }\end{array}$ \\
\hline NUMBER OF REFERENCES & NUMBER OF FIGURES & NUMBER OF TABLES \\
\hline 14 & 0 & 3 \\
\hline
\end{tabular}

(c) The author(s) 2023. This publication is an open access article. 
Elok Sri Utami (Indonesia)

\title{
The effect of the crisis on financial performance of property sector in Indonesia
}

\begin{abstract}
Usually, financial crisis affects the firm's operations with different resistance level, such as financial difficulties and even negative profits or equity. The crisis may affect heavily certain industry, but not in the other industry. This study examines the financial performance of property and real estate firms listed on the Indonesian Stock Exchange which was argued to have been affected by 2008 global financial crisis. Five ratios were examined, namely liquidity ratio, debt to equity ratio, total assets turnover, net profit margin, and return on equity. The sample consists of 27 firms. Results showed that two ratios, debt to equity ratio and return on equity ratio, were significantly lower after the crisis. The other three ratios were not significantly different between before and after the crisis.
\end{abstract}

Keywords: financial crisis, financial performance, property sector, leverage, profitability.

JEL Classification: G01, G32.

Received on: $28^{\text {th }}$ of January, 2017.

Accepted on: $10^{\text {th }}$ of April, 2017.

\section{Introduction}

The global financial economic crisis in 2008 was started from the crisis in the United States, which then, affected other countries in the world, including Indonesia. The crisis severely hit the stock market prices around the world. The crisis has also caused the collapse of many firms operating in the financial and property sectors, which, then, led to the declining of the Dow Jones and Nasdaq Indexes in Wall Street Stock Exchanges. The Indonesian stock market index declined from a record high of around 2,700 at the end of 2007 to around 1,300 by the end of 2008 . It has also caused the collapse of many firms, for example, in Ukraine (Aslud, 2013). The other impact of the crisis was the declining of the Indonesian currency rate, making many investors withdraw their funds, and many banks temporarily stopped distributing credit to the property sector. Thus, this study is directed to test the effect of the 2008 financial crisis on the performance of firms in the property sector listed in the Indonesian Stock Exchange.

The property sector is an attractive and promising business sector for many investors, because, as the population grows, there is an increasing need or demand for the housing. The property sector is also the driver for other real sectors, namely the metal and non-metal processing industries, such as cement or ceramics (Sisbintari, 2012). However, investing in the property sector requires a huge amount of money, as the investment is classified to be long

(C) Elok Sri Utami, 2017.

Elok Sri Utami, Lecturer, Department of Management, Faculty of Economics and Business, University Jember, Indonesia.

This is an Open Access article, distributed under the terms of the Creative Commons Attribution 4.0 International license, which permits unrestricted re-use, distribution, and reproduction in any medium, provided the original work is properly cited term. It is considered to be riskier than any other sectors. The external factors that also affect the property sector are the interest rate, inflation, exchange rate against foreign currencies, and also a stock price index (Darminto, 2008). The high level of interest rates will increase the firm's operating costs, especially for the firms having high loan rate. The declining of the exchange rate also led to higher production cost. This is due to the obligation to pay off the debt (if the debt is in dollars) or the cost of importing the raw materials from other countries.

Surprisingly, the Indonesian property sector survived from the crisis, because this sector was an alternative investment in saving the investors' wealth (Prasetiantoro, 2014). This fact is of interest whether the survival is related to the financial performance of the firms. Several studies have been conducted to analyze the effect of financial crisis on the performance of the firms. For example, Sastrosuwito and Suzuki (2011) examined the determinants of fundamental and macroeconomic factors on the firm's profitability during the 1997 crisis. They found that cost management, debt ratio or capital structure influenced the firm's profitability, while the macro factor did not have effect on the firm's profitability. Tambunan (1997) examined the effect of the 1997 financial crisis on the agricultural sector and found that the intensity of the effect depended on the structure of the source of raw material acquisition (domestic or foreign), marketing structures of the output within or outside the country, and its capital structure. Yudanto and Setiawan (1998) found that the real sector could survive from the crisis, in particular the real sector with strong resource base, export-oriented, having low non-rupiah financing sources, and also having low correlation and elasticity to the changes of the interest rates and exchange rates, able to survive 
and even grew positively during the crisis. The financial performance of a firm is defined as the prospect, growth and developing potential compared to other firms engaged in the same sector (Utami, 2013). The assessment of a firm's financial performance is important as the basis of the process in management decision making in the form of capital utilization effectiveness, efficiency, and profitability. The performance is also related of the firm's activities and the value and security of the various claims against the firm from the third parties.

Thus, it is clear that the economic crisis empirically affects the firm's performance. The current study examined the effect of financial crisis on the financial performance of firms in the property sector listed at Indonesian Stock Exchange for period 2007-2013. Results indicated that debt to equity and return on equity ratio was significantly lower after the crisis.

\section{Literature review}

The global financial crisis which occurred in 2008 started from the Subprime Mortgage fiasco in the middle of 2007 initiated by the collapsed of Lehman Brothers. By the end of 2008 the market index of Indonesian Stock Exchange went down more than $50 \%$ from 2,700 at the beginning year to 1,300 at the end of the year.

Apart from 2008 financial crisis, Indonesia has experienced economic crisis started in 1997. The impact of the crisis was massive not only in terms of economic sector but also in the other sectors. Some referred the crisis as the multidimensional crisis. The crisis has led to the political turmoil causing more deteriorating in economic sector.

Several studies have examined the effect of the 1997 crisis on corporate performance. One of them is Sastrosuwito and Suzuki (2011) who examined the influence of fundamental and macro-economic factors on performance. Results showed that the cost management factor had a negative and significant impact on profitability, while debt ratio concretation of industries had positive effect on profitability. There was no effect of the size of the bank on profitability, and the concentration of industries had a significant and positive effect on profitability. Macroeconomics factor did not have significant effect on profitability of the firms. Tambunan (1997) found that the financial crisis in Indonesia had negative effect on the performance of the related agribusiness.

Yudanto and Setiawan (1998) reported that business in the real sector could survive from the crisis. Their observation showed that the real sector, with a strong resource base, export-oriented, having low non-rupiah financing sources, and low correlation and elasticity toward the changes in interest rates and exchange rates, was proved to be survived and it even had positive growth during the crisis. Referring to such condition, the recommended policy for the short term is creating stable and reasonable interest rates and exchange rates, while for the long term, it is recommended to encourage the restructuring of the real sector in order to be more efficient and competitive in both domestic and export markets.

In the times of crisis, there shall be an increase in liquid funds than normal economic times, because there are changes in purchasing patterns resulting in decreased revenues due to a decrease in purchasing power. Firms with heavy resistance will be experiencing financial difficulties (Sastrosuwito and Suzuki, 2011; Deesomsak et al., 2009; Suk, 2007; Diamond, 1996). Therefore, it is predicted that the liquidity ratio will decrease in the period after the crisis.

The liquidity risk hypothesis predicts that the crisis will lead to increased demand for liquidity for companies with high debt ratios, because they have a high fixed load. Changes to the cash inflow from the crisis could lead to financial distress and bankruptcy (Sastrosuwito and Suzuki, 2011; Deesomsak et al., 2009; Suk, 2007). This will trigger moral hazard problem. However, moral hazard suspect that the role of short-term debt can reduce the agency problem, even though the tax hypothesis states that tax benefits enjoyed by the company as a result of the debt is still smaller than the risk increase due to the crisis (Brick and Ravid, 1985). Therefore, debt ratio (leverage) is predicted to increase after the crisis.

Productivity ratio of well-managed company can reduce the impact of the crisis. Cost management may have significant negative impact on the profitability, as well as the asset turnover ratio. Firms that have high turnover of assets can optimize the fund in the event of a crisis, because the company uses a lower asset for achieving certain revenue (Suk, 2007; Tambunan, 1997). Thus, it is predicted that the total assets turnover will lower after the crisis.

In the period of crisis, the firms' profitability is affected by changes in the cost structure (increasing the cost per unit of inputs and outputs) and the unpredicted sales. For the export-oriented firms, the crisis will have a positive impact, but for firms with domestic market orientation, their profitability during the crisis tend to lower. This is in line with the findings of Juda et al. (2000), Mochtar et al. 
(2005), Nugraha et al. (2005), Deesomsak et al. (2009), and Suk (2007). Thus, it is predicted that profitability will decrease after the crisis.

\section{Research methods}

This research used secondary data obtained from the Indonesian Stock Exchange and the Indonesian Capital Market Directory (ICMD). The sample firms were selected using purposive sampling upon the following criteria:

a. The firm has become a public firm prior to 2007 . If the firm went public after 2007, it is regarded as this relatively new public firm, so that the survival level of the crisis will be different from the firm that has long been a public firm.

b. The firm has never been delisted during the research period, which means that the firm is always reporting its financial report and other obligatory reports.

The variables examined in this study consisted of five financial ratios described as follows:

a. Current ratio, which is a comparison of current assets to current liabilities. b. Total asset turnover, which is the ratio of sales over total assets.

c. Debt total equity ratio, which is the ratio of total debt to total equity.

d. Net profit margin, which is the ratio of net income to sales.

e. Return on equity, which is the ratio of net income to total equity.

To examine whether there is any difference in financial performance, the mean test (Paired Samples t-test) or the median test (Wilcoxon test) were employed. These methods of comparison followed Jain and Kini (1994). The mean or median of that year is compared against the first year up to fifth year after the 2008 global financial crisis.

\section{Results and discussion}

By the end of 2015, there were 48 firms in the property and real estate sub-sector listed at the Indonesian stock market. The selection criteria generated a final sample totaling of 27 firms. Table 1 shows the descriptive statistics for each variable. The year of the crisis was excluded.

Table 1. Statistic descriptive of variables

\begin{tabular}{|c|c|c|c|c|c|c|}
\hline Variable & Period & Mean & Median & Standard deviation & Minimum & Maximum \\
\hline \multirow{6}{*}{$\begin{array}{l}\text { CR } \\
(\%)\end{array}$} & $\mathrm{t}-1$ & 2.053 & 1.380 & 2.650 & 0.110 & 11.820 \\
\hline & $t+1$ & 3.393 & 1.773 & 5.056 & 0.170 & 23.800 \\
\hline & $t+2$ & 2.900 & 1.988 & 3.155 & 0.220 & 14.630 \\
\hline & $t+3$ & 2.724 & 1.680 & 2.859 & 0.200 & 13.600 \\
\hline & $t+4$ & 2.203 & 1.572 & 1.287 & 0.670 & 5.910 \\
\hline & $t+5$ & 2.060 & 1.616 & 1.319 & 0.320 & 4.960 \\
\hline \multirow{6}{*}{$\begin{array}{l}\text { TATO } \\
\text { (times) }\end{array}$} & $t-1$ & 0.361 & 0.220 & 0.334 & 0.030 & 1.150 \\
\hline & $t+1$ & 0.330 & 0.206 & 0.398 & 0.040 & 1.370 \\
\hline & $t+2$ & 0.313 & 0.212 & 0.305 & 0.040 & 1.150 \\
\hline & $t+3$ & 0.316 & 0.219 & 0.284 & 0.020 & 1.100 \\
\hline & $t+4$ & 0.296 & 0.223 & 0.261 & 0.010 & 0.970 \\
\hline & $t+5$ & 0.314 & 0.227 & 0.283 & 0.010 & 1.030 \\
\hline \multirow{6}{*}{$\begin{array}{l}\text { DER } \\
(\%)\end{array}$} & $t-1$ & 1.820 & 1.450 & 1.816 & 0.120 & 7.130 \\
\hline & $t+1$ & 1.419 & 0.990 & 1.435 & 0.050 & 6.690 \\
\hline & $t+2$ & 1.158 & 0.930 & 1.032 & 0.070 & 4.710 \\
\hline & $t+3$ & 1.097 & 0.830 & 1.104 & 0.080 & 5.170 \\
\hline & $t+4$ & 1.142 & 0.780 & 1.236 & 0.080 & 5.670 \\
\hline & $t+5$ & 1.159 & 0.680 & 1.172 & 0.240 & 5.280 \\
\hline \multirow{6}{*}{$\begin{array}{l}\text { PM } \\
(\%)\end{array}$} & $t-1$ & 0.191 & 0.090 & 0.301 & -0.020 & 1.400 \\
\hline & $t+1$ & 0.076 & 0.102 & 0.211 & -0.710 & 0.420 \\
\hline & $t+2$ & 0.120 & 0.131 & 0.163 & -0.330 & 0.440 \\
\hline & $t+3$ & 0.143 & 0.194 & 0.412 & -1.170 & 1.000 \\
\hline & $t+4$ & -0.003 & 0.225 & 1.000 & -4.460 & 0.500 \\
\hline & $t+5$ & -0.003 & 0.148 & 1.242 & -5.360 & 1.760 \\
\hline \multirow{6}{*}{$\begin{array}{l}\text { ROE } \\
(\%)\end{array}$} & $t-1$ & 2.938 & 3.250 & 14.777 & -58.250 & 21.010 \\
\hline & $t+1$ & 0.064 & 0.052 & 0.095 & -0.220 & 0.280 \\
\hline & $t+2$ & 0.083 & 0.065 & 0.082 & -0.050 & 0.260 \\
\hline & $t+3$ & 0.097 & 0.093 & 0.121 & -0.270 & 0.310 \\
\hline & $t+4$ & 0.106 & 0.096 & 0.120 & -0.190 & 0.330 \\
\hline & $t+5$ & 0.105 & 0.112 & 0.116 & -0.110 & 0.330 \\
\hline
\end{tabular}

Note: $\mathrm{CR}=$ current ratio, $\mathrm{TATO}=$ total assets turnover, $\mathrm{DER}=$ debt equity ratio, $\mathrm{NPM}=$ net profit margin, $\mathrm{ROE}=$ return on equity. 
As can be seen in Table 1, the average current ratio (CR) increases to a peak in two years after the crisis and, then, decreases again up to the fifth year. The average value of total assets turnover (TATO) decreases after the crisis and tends to stabilize. The average value of debt equity ratio (DER) decreases after the crisis and continues to decline until 3 years after the crisis and, then, increases slightly until the fifth year. The average value of net profit margin (NPM) decreases after the crisis and continues to decline up to year five after the crisis. The mean return on equity (ROE) decreases after the crisis and continues to decline until 3 years after the crisis and, then, begins to rise in the fourth and fifth years. Overall, the ratios tend to decline over five years after the crisis.

Results from the descriptive statistics (Table 1) seem to confirm that the crisis has made the firms' financial performance to worsen. This is in line with the prediction and the results of previous studies that assert that the firms were severely affected by the financial crisis.

Prior to testing the hypothesis, the distribution of data was examined to check for the normality. The results of normality tests are shown in Table 2.

Table 2. Results of tests of data normality

\begin{tabular}{|l|c|c|c|c|c|}
\hline \multirow{2}{*}{ Description } & \multicolumn{5}{|c|}{ Year relative to economic crisis } \\
\cline { 2 - 6 } & -1 to +1 & -1 to +2 & -1 to +3 & -1 to +4 & -1 to +5 \\
\hline CR & $\begin{array}{c}\text { not } \\
\text { normal }\end{array}$ & $\begin{array}{c}\text { not } \\
\text { normal }\end{array}$ & $\begin{array}{c}\text { not } \\
\text { normal }\end{array}$ & $\begin{array}{c}\text { not } \\
\text { normal }\end{array}$ & $\begin{array}{c}\text { not } \\
\text { normal }\end{array}$ \\
\hline TATO & $\begin{array}{c}\text { not } \\
\text { normal }\end{array}$ & $\begin{array}{c}\text { not } \\
\text { normal }\end{array}$ & $\begin{array}{c}\text { not } \\
\text { normal }\end{array}$ & $\begin{array}{c}\text { not } \\
\text { normal }\end{array}$ & $\begin{array}{c}\text { not } \\
\text { normal }\end{array}$ \\
\hline DER & Normal & normal & normal & normal & normal \\
\hline NPM & $\begin{array}{c}\text { not } \\
\text { normal }\end{array}$ & $\begin{array}{c}\text { not } \\
\text { normal }\end{array}$ & $\begin{array}{c}\text { not } \\
\text { normal }\end{array}$ & $\begin{array}{c}\text { not } \\
\text { normal }\end{array}$ & $\begin{array}{c}\text { not } \\
\text { normal }\end{array}$ \\
\hline ROE & $\begin{array}{c}\text { not } \\
\text { normal }\end{array}$ & $\begin{array}{c}\text { not } \\
\text { normal }\end{array}$ & $\begin{array}{c}\text { not } \\
\text { normal }\end{array}$ & $\begin{array}{c}\text { not } \\
\text { normal }\end{array}$ & $\begin{array}{c}\text { not } \\
\text { normal }\end{array}$ \\
\hline
\end{tabular}

Note: $\mathrm{CR}=$ current ratio, $\mathrm{TATO}=$ total assets turnover, $\mathrm{DER}=$ $=$ debt equity ratio, $\mathrm{NPM}=$ net profit margin, $\mathrm{ROE}=$ return on equity.

As shown the Table 2, not all of the data have normal distribution. If the pattern of the data between the testing year of a year before the crisis has normal distribution, but when the distribution of the comparable years is not normal, the testing is conducted using median test (non-parametric test). If the distribution of the data is normal, then, the mean test (parametric test) is employed.

Summary of results of tests for the performance difference before and after the crisis is shown in Table 3. Panel A of Table 3 shows the results that the mean current ratio (CR) increases one year after the crisis and was different from the one before the crisis ( $\mathrm{p}<10 \%)$, while for two to five years after the crisis, there is no significant difference. This indicates that in one year after the crisis, there was a difference in the form of an increase in the firm's liquidity. The increase was due to the inflation as the impact of the crisis. The result supports Tambunan (1997) who states that for the sector with domestic cost oriented, the crisis did not have big impact, while Yudanto and Santoso (1998) found that the property sector was a real sector with low non-rupiah financing sources, so that the changes in the high exchange rates that were due to the crisis would not affect this sector.

Panel B of Table 3 shows that the means of total assets to turnover (TATO) before and after the crisis have decreased during the five years' time period of observation, but the changes were not statistically different. These findings indicate that on average, the firms in the property sector have no different effectiveness in asset management to create sales before and after the crisis. The findings also support those of Tambunan (1997) and Yudanto and Santoso (1998) that the crisis had no effect on the firm with the marketing structure of its output focusing on domestic market, such as the property sector as part of the real sector having low non-rupiah financing sources.

Panel $\mathrm{C}$ of Table 3 shows that the mean of debt to equity (DER) decreases one year after and one year prior to the crisis, but not statistically significant. In the two to four years after the crisis, the average values of DER tend to decrease compared to the value at the basic year, and significant at the 5\% level, while in the fifth year it was significant at the $10 \%$ level. In general, the results indicate that the DER after the crisis is different from the pre-crisis DER. The results show a contrary prediction, because many property firms have decreased the amount of debt compared to its equity. The prediction was that the crisis would have an impact on the increase of the operational funding needs that will finally increase the firm's debt. This indicates that for the property sector, the crisis, in fact, gives a positive impact in lowering the debt levels. Such condition happened, because when the interest rates and exchange rates changed, people prefered to spend their money in the real sector and resulting in high cash flow in this sector, because most customers used cash payment system. The increase in the cash flow is, then, used to pay off the debts of the firm, resulting in the reduction of the debt amount started from two to five years after the crisis.

Panel D of Table 3 shows that the median change values of the net profit margin (NPM) fluctuate. However, the values were likely to increase up to three years after the crisis. But in the fourth year after the crisis, it decreased again and in the fifth year it increased, though the differences of NPM were not statistically significant. In general, the 
findings show that NPM did not differ before and after the crisis. These findings indicate that in average, the profit ability of the firm in property sector was determined by sales changes, so the effectiveness of the achieved profitability of the sales before and after the crisis was not different.

Table 3. Results of test of mean (median) difference of financial performance, before and after the crisis

\begin{tabular}{|c|c|c|c|c|c|}
\hline \multirow{2}{*}{ Description } & \multicolumn{5}{|c|}{ Year relative to economic crisis } \\
\hline & -1 to +1 & -1 to +2 & -1 to +3 & -1 to +4 & -1 to +5 \\
\hline \multicolumn{6}{|c|}{ Panel A. Current ratio (CR) } \\
\hline Median (\%) & $1.380 ; 1.773$ & $1.380 ; 1.988$ & $1.380 ; 1.680$ & $1.380 ; 1.572$ & $1.380 ; 1.616$ \\
\hline Median diff. (\%) & $0.393^{*}$ & 0.608 & 0.300 & 0.192 & 0.236 \\
\hline Mean $(\%)$ & $2.053 ; 3.393$ & $2.053 ; 2.899$ & $2.053 ; 2.724$ & $2.053 ; 2.203$ & $2.053 ; 2.060$ \\
\hline Mean diff. (\%) & 1.34 & 0.846 & 0.671 & 0.15 & 0.007 \\
\hline p-value (median) & 0.064 & 0.162 & 0.248 & 0.218 & 0.429 \\
\hline$p$-value (Mean) & 0.114 & 0.164 & 0.343 & 0.793 & 0.990 \\
\hline Null hypothesis & rejected & accepted & accepted & accepted & accepted \\
\hline \multicolumn{6}{|c|}{ Panel B. Total assets turn over (TATO) } \\
\hline Median (\%) & $0.220 ; 0.206$ & $0.220 ; 0.212$ & $0.220 ; 0.219$ & $0.220 ; 0.223$ & $0.220 ; 0.227$ \\
\hline Median diff.(\%) & -0.014 & -0.008 & -0.001 & 0.003 & 0.007 \\
\hline Mean $(\%)$ & $0.360 ; 0.330$ & $0.360 ; 0.313$ & $0.360 ; 0.316$ & $0.360 ; 0.296$ & $0.360 ; 0.314$ \\
\hline Mean diff. (\%) & -1.44 & -1.457 & -1.454 & -1.474 & -1.456 \\
\hline p-value (median) & 0.429 & 0.370 & 0.301 & 0.316 & 0.447 \\
\hline p-value (Mean) & 0.457 & 0.311 & 0.26 & 0.11 & 0.202 \\
\hline Null hypothesis & accepted & accepted & accepted & accepted & accepted \\
\hline \multicolumn{6}{|c|}{ Panel C. Debt equity ratio( DER) } \\
\hline Median (\%) & $1.450 ; 0.990$ & $1.450 ; 0.930$ & $1.450 ; 0.830$ & $1.450 ; 0.780$ & $1.450 ; 0.680$ \\
\hline Median diff. (\%) & -0.460 & -0.480 & -0.620 & -0.670 & -0.770 \\
\hline Mean $(\%)$ & $1.819 ; 1.419$ & $1.819 ; 1.158$ & $1.819 ; 1.097$ & $1.819 ; 1.142$ & $1.819 ; 1.159$ \\
\hline Mean diff. (\%) & -0.400 & $-0.661^{\star *}$ & $-0.722^{* *}$ & $-0.677^{* \star}$ & $-0.660^{*}$ \\
\hline p-value (median) & 0.171 & 0.046 & 0.053 & 0.100 & 0.114 \\
\hline p-value (Mean) & 0.167 & 0.036 & 0.036 & 0.05 & 0.062 \\
\hline Null hypothesis & accepted & rejected & rejected & rejected & rejected \\
\hline \multicolumn{6}{|c|}{ Panel D. Net profit margin (NPM) } \\
\hline Median (\%) & $0.090 ; 0.102$ & $0.090 ; 0.131$ & $0.090 ; 0.194$ & $0.090 ;-0.225$ & $0.090 ;-0.148$ \\
\hline Median diff. (\%) & 0.012 & 0.041 & 0.104 & -0.315 & 0.058 \\
\hline Mean $(\%)$ & $0.191 ; 0.076$ & $0.191 ; 0.120$ & $0.191 ; 0.143$ & $0.191 ;-0.026$ & $0.191 ;-0.003$ \\
\hline Mean diff. (\%) & -0.115 & -0.071 & -0.048 & -0.217 & -0.194 \\
\hline $\mathrm{p}$-value (median) & 0.429 & 0.738 & 0.316 & 0.26 & 0.563 \\
\hline p-value (Mean) & 0.155 & 0.274 & 0.66 & 0.377 & 0.460 \\
\hline Null hypothesis & accepted & accepted & accepted & accepted & accepted \\
\hline \multicolumn{6}{|c|}{ Panel E. Return on equity (ROE) } \\
\hline Median (\%) & $3.250 ; 0.052$ & $3.250 ; 0.065$ & $3.250 ; 0.093$ & $3.250 ; 0.096$ & $3.250 ; 0.112$ \\
\hline Median diff. (\%) & $-3.198^{\star * *}$ & $-3.185^{\star \star \star}$ & $-3.343^{\star * \star}$ & $-3.154^{\star \star *}$ & $-3.138^{* \star *}$ \\
\hline Mean $(\%)$ & $2.938 ; 0.064$ & $2.938 ; 0.083$ & 2.938; 0.097 & $2.938 ; 0.106$ & $2.938 ; 0.105$ \\
\hline Mean diff. (\%) & -2.874 & -2.854 & -2.84 & -2.831 & -2.832 \\
\hline $\mathrm{p}$-value (median) & 0.002 & 0.002 & 0.002 & 0.002 & 0.002 \\
\hline p-value (Mean) & 0.306 & 0.363 & 0.366 & 0.367 & 0.367 \\
\hline Null hypothesis & rejected & rejected & rejected & rejected & rejected \\
\hline
\end{tabular}

Note: $* * *, * * *$ indicate significant at $1 \%, 5 \%$, and $10 \%$ level, respectively.

Panel E of Table 3 shows that there was significant decline in the return on equity (ROE) between one year before and five years after the crisis. These findings confirm the prediction that the firms' ability to generate profits is decreasing. The declining of ROE after the crisis can also be associated with the reduction in debt to equity level. The declining debt level will have an impact on lower interest expenses and the firm will pay higher taxes. Higher tax payment will have an impact on lower profits for the owners that it will eventually lead to the declining of ROE.

\section{Conclusion}

The study shows that there was no difference in the performance of the current ratio, total asset turnover, and net profit margin among the tested periods, which are between before and after the 
global financial crisis of 2008. The debt equity ratio and the return on equity have significant difference between before and after the crisis. The findings showed that in the two to four years after the crisis, the average value of the debt to equity ratios tend to decrease compared to the pre-crisis period. This indicates that the 2008 crisis has relatively better impact on the property sector, as the fact showed that the amount of debt was getting lower compared to its equity after the crisis. This indicates that this sector has a strong resource base and for the investors and the society, the property sector was a good alternative investment. But, for the owners, the crisis had no positive impact, because there was a declining on profit after the crisis. However, overall, the property sector was able to survive during the crisis, because the return on equity was still positive.

Future research could observe the macroeconomic variables, because it is predicted that macro economic factors can also define and influence the performance of the firm. In addition, the future research can also use sample from several industries. By observing the effect of the industry, it is expected that the research will gain information about the type of industry that will be potentially affected by the crisis and which ones that will not be so affected by the crisis.

\section{References}

1. Aslud, A. (2013). Ukraine's Financial Crisis 2009. Eurasian Geography and Economics Journal, 50(4), 371-386.

2. Brick, L., and Ravid, S. (1985). On The relevance of debt maturity Structure. Journal of Finance, 40(4), 1423-1437.

3. Deesomsak, R., Paudyal, K., and Pescetto, G. (2009). Debt Maturity Structure and the 1997 Asian Financial Crisis. Journal of Multinational Financial Management, 19(1), 26-42.

4. Diamond, D. (1996). Debt maturity structure and Liqudity risk. Quarterly Journal of Economics, 106, 709-737.

5. Ikatan Akuntan Indonesia. (2000). Standar Akuntansi Keuangan (Financial Accounting Standards). PenerbitSalemba Empat, Jakarta.

6. Jain, B. A., and Kini, O. (1994). The Post Issue Operating Performance of IPO Firms. Journal of Finance, 49(5), 1699-1726.

7. Nugraha, P. (2008). Dampak Financing Deepening terhadap Pelaksanaan Kebijakan Moneter di Indonesia. Report of Research by Federal Reserve Bank of Indonesia.

8. Prasetiantoro, T. (2008). Impact of Global Financial Crisis against Indonesia. Retrieved on July 20, 2015 from http://www.prase tya.ub.ac.id/berita.

9. Sastrosuwito, S., and Suzuki, Y. (2011). Post Crisis Indonesian Banking System Profitability: Bank Specific, Industry Specificand Macroeconomic Determinants. The $2^{\text {nd }}$ International Research Symposium in Service management. Yogyakarta-Indonesia.

10. Sisbintari, I. (2012). Analisis Komparatif Harga saham Sebelumdan Sesudah Pembagian Dividen: Studipada Perusahaan Propertiyang Terdaftardi Bursa Efek Indonesia Tahun 2010 (The Comparative analysis of stock price before and after the dividend payment: Study on Property Firm Listed in Indonesia Stock Exchange in 2010). Jurnal Kebijakan Publikdan Bisnis, 3(1), 68-79.

11. Suk, K. S. (2007). Dinamika Pemodelan Financial Distress Perusahaan Publik di Indonesia (Modelling Dynamic of Financial Distress of Public Firm in Indonesia). Jurnal Akuntansi dan Keuangan, 1(3), 187-204.

12. Tambunan, M. (1997). Prakiraan Dampak Krisis Keuangan Terhadap Ekonomi, Khususnya Sektor Pertanian dan Agribisnis di Indonesia (The Against Financial Crisis Impact Forecast on Economy, Agriculture and Agribusiness Particularly in Indonesia), Seminar PusatStudi Pembangunan Lembaga Penelitian. Institut Pertanian Bogor.

13. Utami, E. S. (2013). Kinerja Finansial Perusahaan Yang Melakukan Akuisisi (Firm Financial Performance Conducting Acquisition). Jurnal Akuntansi Universitas Jember, 11(2), 48-61.

14. Yudanto, N., and Setyawan, S. M. (1998). Dampak Krisis Moneter Terhadap Sektor Riil (Impact of Monetary Crisis on Real Sector). Buletin Ekonomi Moneter dan Perbankan, 1(2), 131-158. 